\title{
Resident perception of volcanic hazards and evacuation procedures
}

\author{
D. K. Bird ${ }^{1,2}$, G. Gisladottir ${ }^{2}$, and D.Dominey-Howes ${ }^{3}$ \\ ${ }^{1}$ Department of Environment and Geography, Macquarie University, North Ryde, Sydney, NSW 2109, Australia \\ ${ }^{2}$ Department of Geography and Tourism, Faculty of Life and Environmental Sciences, Askja, University of Iceland, \\ 101 Reykjavík, Iceland \\ ${ }^{3}$ Natural Hazards Research Laboratory, School of Biological, Earth and Environmental Sciences, University of New South \\ Wales, Sydney, NSW 2052, Australia
}

Received: 17 September 2008 - Revised: 17 February 2009 - Accepted: 17 February 2009 - Published: 27 February 2009

\begin{abstract}
Katla volcano, located beneath the Mýrdalsjökull ice cap in southern Iceland, is capable of producing catastrophic jökulhlaup. The Icelandic Civil Protection (ICP), in conjunction with scientists, local police and emergency managers, developed mitigation strategies for possible jökulhlaup produced during future Katla eruptions. These strategies were tested during a full-scale evacuation exercise in March 2006. A positive public response during a volcanic crisis not only depends upon the public's knowledge of the evacuation plan but also their knowledge and perception of the possible hazards. To improve the effectiveness of residents' compliance with warning and evacuation messages it is important that emergency management officials understand how the public interpret their situation in relation to volcanic hazards and their potential response during a crisis and apply this information to the ongoing development of risk mitigation strategies. We adopted a mixed methods approach in order to gain a broad understanding of residents' knowledge and perception of the Katla volcano in general, jökulhlaup hazards specifically and the regional emergency evacuation plan. This entailed field observations during the major evacuation exercise, interviews with key emergency management officials and questionnaire survey interviews with local residents. Our survey shows that despite living within the hazard zone, many residents do not perceive that their homes could be affected by a jökulhlaup, and many participants who perceive that their homes are safe, stated that they would not evacuate if an evacuation warning was issued. Alarmingly, most participants did not receive an evacuation message during the exercise. However, the majority of participants who took part in the exercise were positive about its implementa-
\end{abstract}

Correspondence to: D. K. Bird

(dbird@els.mq.edu.au) tion. This assessment of resident knowledge and perception of volcanic hazards and the evacuation plan is the first of its kind in this region. Our data can be used as a baseline by the ICP for more detailed studies in Iceland's volcanic regions.

\section{Introduction}

The Icelandic term "jökulhlaup" is defined as a sudden burst of meltwater from a glacier and may occur for a period of several minutes to several weeks (Björnsson, 2002). All confirmed historic eruptions of Katla, the volcano underlying the Mýrdalsjökull ice cap in southern Iceland (Fig. 1), have produced jökulhlaup (Thordarson and Larsen, 2007). A Katla eruption can melt through the $\sim 400 \mathrm{~m}$ of ice covering the Katla caldera in $1-2 \mathrm{~h}$, producing a catastrophic jökulhlaup with a peak discharge of $100000-300000 \mathrm{~m}^{3} \mathrm{~s}^{-1}$ (Björnsson, 2002).

Transporting volcanic debris and large ice blocks, jökulhlaup have been the most serious hazard during historic Katla eruptions but not the only hazard. Local communities $30 \mathrm{~km}$ from the eruption site have been subjected to heavy tephra fallout and lightning strikes (Larsen, 2000) while jökulhlaup have triggered small tsunami during past volcanic events (Guðmundsson et al., 2008). Earthquakes, felt by local communities, signify the start of an eruption. They are not however, of sufficient magnitude to cause major damage (Guðmundsson et al., 2008). Furthermore, not all Katla eruptions have been subglacial. Lava covered $\sim 780 \mathrm{~km}^{2}$ of land during the 934-938 AD Eldgjá flood lava eruption which occurred along a $75 \mathrm{~km}$ discontinuous and predominately subaerial volcanic fissure extending from the Katla caldera (Thordarson and Larsen, 2007).

Published by Copernicus Publications on behalf of the European Geosciences Union. 


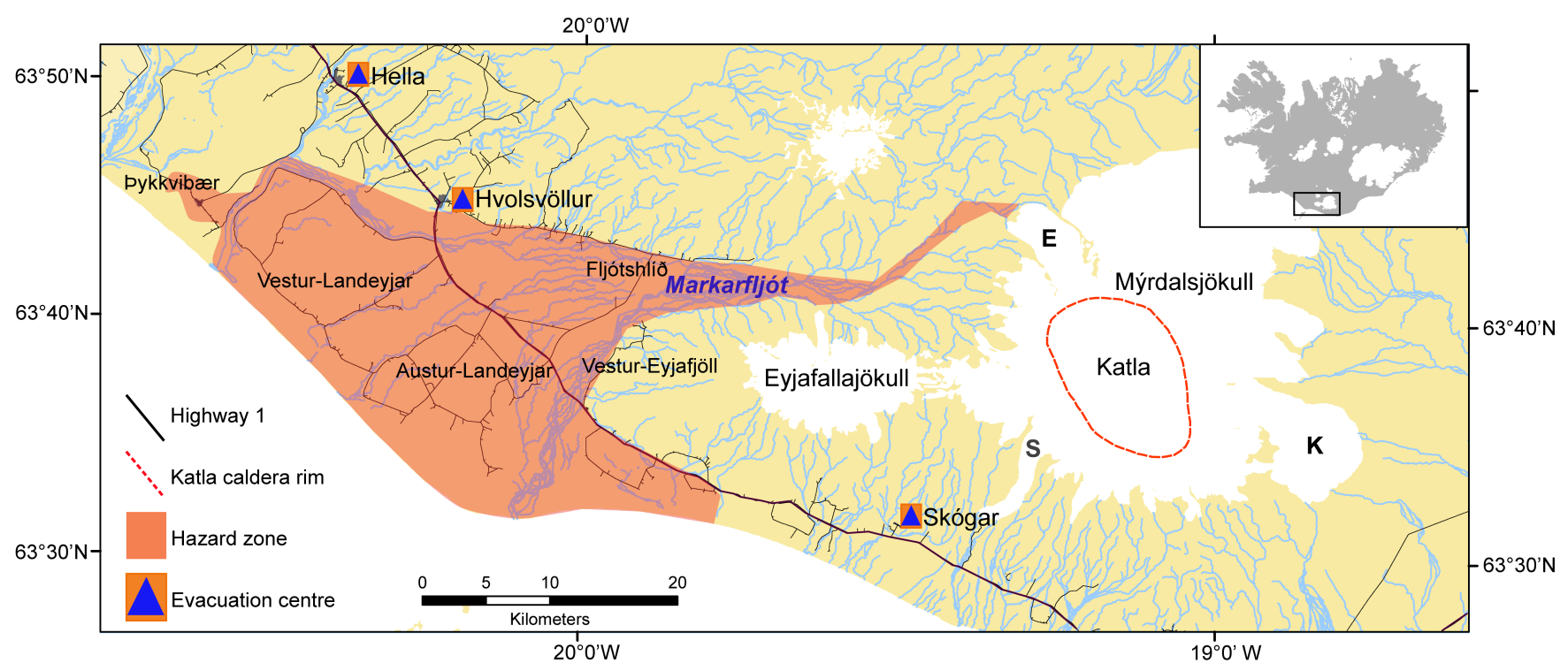

Fig. 1. The jökulhlaup hazard zone of Rangávallasýsla. The hazard zone is determined to be the maximum flood area for a catastrophic jökulhlaup. Communities located within the hazard zone are Vestur-Eyjafjöll, Fljótshlíð, Austur and Vestur-Landeyjar and Pykkvibær. Evacuation centres are located in Hella, Hvolsvöllur and Skógar. The three catchment areas of Mýrdalsjökull: Entujökull, Sólheimajökull and Kötlujökull are represented by E, S and K respectively.

Since settlement in the 9th century Katla has erupted approximately 1-3 times per century (Thordarson and Larsen, 2007). At least 21 eruptions have occurred during this time with the last confirmed eruption in $1918 \mathrm{AD}$ (Larsen, 2000). All historic jökulhlaup have emanated from the catchment areas of Kötlujökull and Sólheimajökull while none have come from the Entujökull catchment. Unconfirmed volcanic activity may have created the jökulhlaup which occurred in $1955 \mathrm{AD}$ and $1999 \mathrm{AD}$ from the Kötlujökull and Sólheimajökull catchments, respectively (Björnsson et al., 2000; Russell et al., 2000; Guðmundsson, 2005).

The Markarfljót valley was subjected to volcanic jökulhlaup emanating from the Entujökull catchment prior to settlement. A series of large, valley-filling prehistoric jökulhlaup were identified by Smith (2004) and Larsen et al. (2005) from sedimentary deposits within the Markarfljót valley. Further, Smith and Haraldsson (2005) determined that the last volcanic jökulhlaup on the Markarfljót occurred 1200 yrs before present. Other types of jökulhlaup have flooded the Markarfljót in more recent times. In $1967 \mathrm{AD}$, a rock/ice avalanche caused an outburst flood from the proglacial lake of Steinsholtsjökull on the northern flank of Eyjafjallajökull. This flood transported boulders measuring up to $80 \mathrm{~m}^{3} 5 \mathrm{~km}$ from the rockslide scar (Kjartansson, 1967). Lastly, geothermal meltwater drains from subglacial lakes in small, more frequent jökulhlaup from all three catchment areas (Björnsson et al., 2000).

Flood simulation models based on data from prehistoric jökulhlaup were used to identify peak discharge and temporal and spatial distribution of a possible catastrophic jökulhlaup flooding from the Entujökull catchment down the Markarfljót (Hólm and Kjaran, 2005). This populated farming region forms part of the Rangávallasýsla municipality. The models show that a catastrophic jökulhlaup with a peak discharge of $300000 \mathrm{~m}^{3} \mathrm{~s}^{-1}$ would reach its maximum within $2 \mathrm{~h}$, flooding to a depth of up to $15 \mathrm{~m}$, at the uppermost farms in Fljótshlíð and up to $10 \mathrm{~m}$ in Vestur-Eyjafjöll. However, many of the farmhouses in these communities are elevated above the floodplain. In contrast, the roads leading up to these farms parallel the Markarfljót and some sections of these roads are positioned at similar base heights to the river channel. Dykes approximately $2 \mathrm{~m}$ in height have been constructed to protect the roads but these flood mitigation structures were not built to withstand a catastrophic jökulhlaup. Within $3 \mathrm{~h}$ Highway 1 would be inundated and the entire outwash plain surrounding the Markarfljót would be flooded within $10 \mathrm{~h}$. With a maximum flood depth of up to $2 \mathrm{~m}$, low lying regions could remain submerged for over $24 \mathrm{~h}$.

In view of the potential future hazard presented by jökulhlaup, the Icelandic Civil Protection organisation (ICP) developed regional evacuation strategies based on a worst case scenario as described in the report edited by Guðmundsson and Gylfason (2005). This report and consequent strategies were the culmination of a multidisciplinary investigation into the physical threat of jökulhlaup produced from a Katla eruption. It did not however, include research from a societal aspect. Researchers argue that a collaboration between the physical and social sciences is a key step toward achieving a greater understanding of the consequences of volcanic hazards (e.g. Johnston et al., 1999). Following the investigation 
communication sessions were held with residents from communities located within the hazard zone in Rangávallasýsla: Vestur-Eyjafjöll, Fljótshlíð, Landeyjar and Pykkvibær. These consisted of information meetings in 2005 and 2006 regarding the possibility of a future Katla eruption and the proposed evacuation plan for a jökulhlaup hazard. During these meetings residents were informed that they could collect an evacuation and hazard information sign from local police (Fig. 2) (K. Porkelsson, personal communication, 2006).

If an eruption is imminent residents would be notified via a text message to their mobile phone. If residents do not have a registered mobile phone number a recorded message would call through to their landline. Upon receiving this message residents have 30 minutes to prepare to evacuate. However, if an eruption occurs without precursory activity, residents will be instructed to evacuate immediately. Before leaving, they are required to hang the evacuation sign outside their house to indicate that they have left. Certain residents in each region have volunteered to 'sweep' their local area to ensure their neighbours have left for the evacuation centres located in Hella, Hvolsvöllur and Skógar. In order to reach these centres some residents must evacuate via the roads that parallel the Markarfljót and along Highway 1.

To test the proposed evacuation plan the ICP conducted a full scale evacuation exercise on 26 March 2006 in Rangávallasýsla. Approximately 1200 residents live within the hazard zone (K. Porkelsson, personal communication, 2006) and for the purpose of fully testing the evacuation plan residents were not informed of the timing of the eruption scenario. Instead residents were instructed to go about their business as usual until they received an evacuation message (R. Ólafsson, personal communication, 2006). The mock eruption began at 10:55 local time (LT) and the first evacuation message was communicated to residents at 10:59 LT. Residents then had 30 minutes to complete the instructions on the hazard sign (Fig. 2) before evacuating their homes to their designated centre.

To improve the effectiveness of residents' compliance with warning and evacuation messages it is important that emergency management officials understand how the public interpret their situation in relation to volcanic hazards and their potential response during a crisis (Ronan et al., 2000; Dominey-Howes and Minos-Minopoulos, 2004; Gregg et al., 2004; Bird and Dominey-Howes, 2006, 2008; Haynes et al., 2008; Paton et al., 2008). Therefore, this study (1) investigates resident's knowledge and perception of Katla, jökulhlaup hazard and their views of the evacuation plan and exercise, and (2) reports the findings to help the ICP improve mitigation strategies. To achieve this, field observations were made during the evacuation exercise, semi-structured interviews with key emergency management officials were held after the evacuation exercise, and questionnaire survey interviews were conducted with local residents. The rationale for using this sequential mixed methods approach is to better understand the evacuation procedure from both a manage- ment and public perspective and to develop and implement a questionnaire survey interview to further explore participant views and knowledge. Before addressing the aim of our research we will describe the methods used to conduct the analysis.

\section{Methods}

A mixed methods approach, drawing from both qualitative and quantitative data collection practices was used to obtain public perception data. We were invited to observe the evacuation exercise from within the emergency headquarters (EH) in Hella in addition to monitoring the proceedings at the evacuation centres (EC) in Hvolsvöllur and Hella. Following the exercise, we conducted semi-structured interviews with emergency management officials and face-to-face questionnaire survey interviews with local residents living within the hazard zone. Public perception research based solely on data generated from questionnaire surveys is unable to capture the complexity of a hazard in a societal context whereas a mixedmethods approach, employing both qualitative and quantitative techniques, provides the researcher with the opportunity to acquire a variety of information on the same topic allowing for a more accurate interpretation of the issues at hand (Horlick-Jones et al., 2003; Haynes et al., 2007). In this section, we describe the methods employed for field observations and interviews followed by those adopted to construct and deliver the questionnaire survey.

\subsection{Observing the evacuation exercise}

Located within the main EH, we (Bird and Gisladottir) observed and documented the development and management of the evacuation exercise. We were at the EH during the most critical stages of the eruption scenario. As the eruption developed we visited the EC in Hella and Hvolsvöllur to observe the emergency management proceedings of the Red Cross and to witness how the public behaved and responded to the evacuation. Some informal discussions were held with evacuees and Red Cross personnel at both centres. During our observations we made written notes to ensure the most significant points were recorded.

\subsection{Interviewing emergency management officials}

Follow-up interviews were conducted with the project manager of ICP, the Chief of Police in Rangávallasýsla, the president of the Icelandic Association for Search and Rescue (ICE-SAR), a research scientist involved in the hazard assessment report and coordination of the eruption scenario for the evacuation exercise, a regional manager for the Red Cross, and the Director of Communication for the Red Cross. The format of the interview was semi-structured whereby specific questions were asked about their departments' role in an emergency situation, their role during the exercise, 


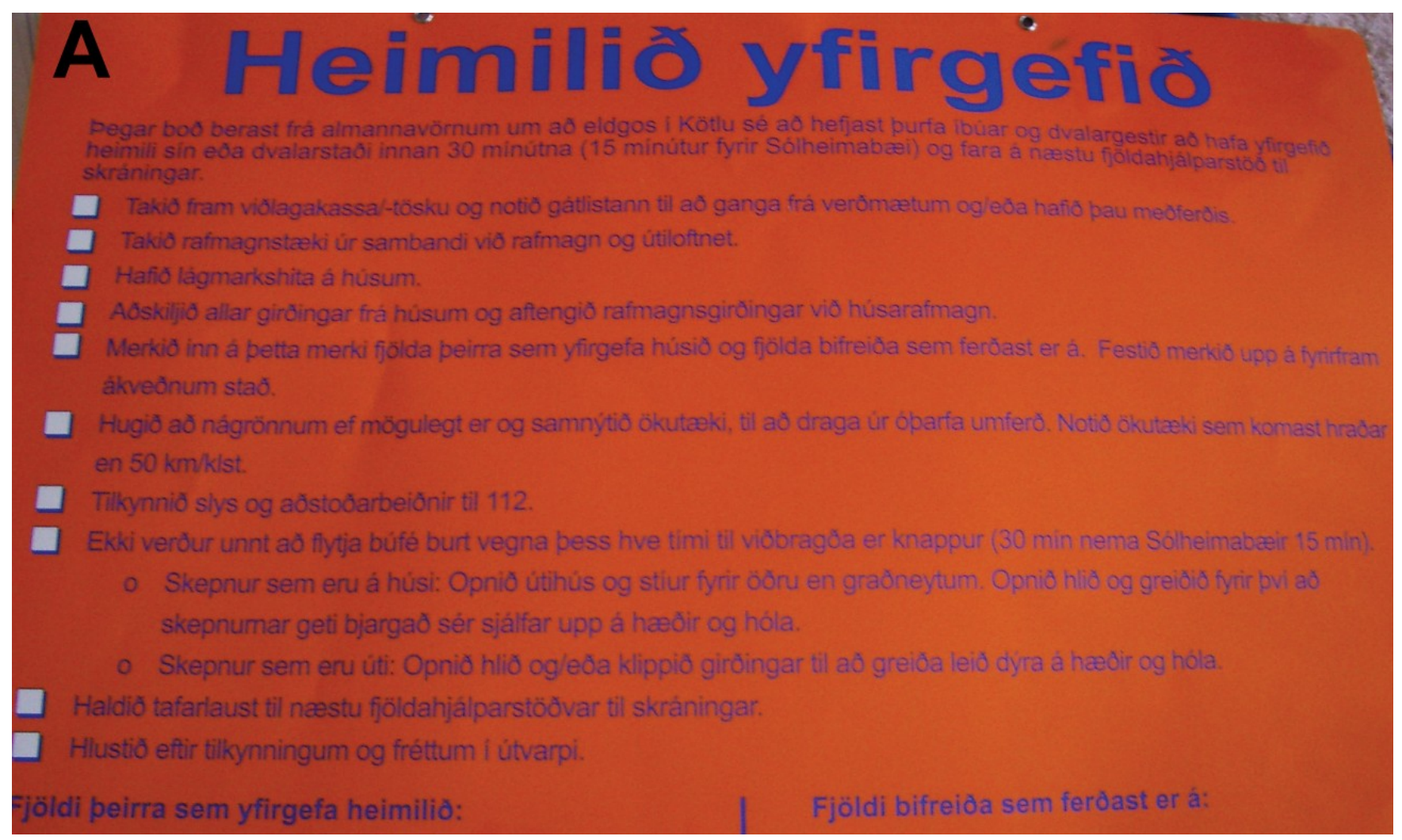

Fig. 2. Evacuation and hazard information sign distributed to residents located in the volcanic hazard zone surrounding Katla. English translations follow.

\section{A House Evacuation (front)}

When a warning is given by the ICP that an eruption in Katla is starting residents and their guests must evacuate within 30 min (15 min for Sólheimar) to the nearest evacuation centre.

- Get the first aid kit, follow this list and secure or collect the valuables you want to take with you.

- Unplug all electrical equipment as well as antennas.

- Set household heaters to a minimum temperature.

- Remove fencing from the house and unplug all electric fences from the house electricity.

- In the space provided indicate how many people have evacuated from this property and the number of vehicles used to evacuate. Fasten this sign on the predetermined spot.

- Check on neighbours if possible and share vehicles to avoid unnecessary traffic. Use vehicles that can drive faster than $50 \mathrm{~km} / \mathrm{hr}$.

- Call 112 if there has been an accident or if you need help.

- It is not possible to move animals due to short evacuation time (30 min, except for Sólheimar $15 \mathrm{~min}$ ).

- For animals that are housed, open the house and pen for all animals except bulls. Open gates and ensure that they can flee to higher ground.

- For animals that are outside, open gate and/or cut fences so that they can flee to higher ground.

- Go straight to the nearest evacuation centre and register.

- Listen to announcements and news on radio.

Number of people evacuated from house: Number of vehicles used for evacuation: 

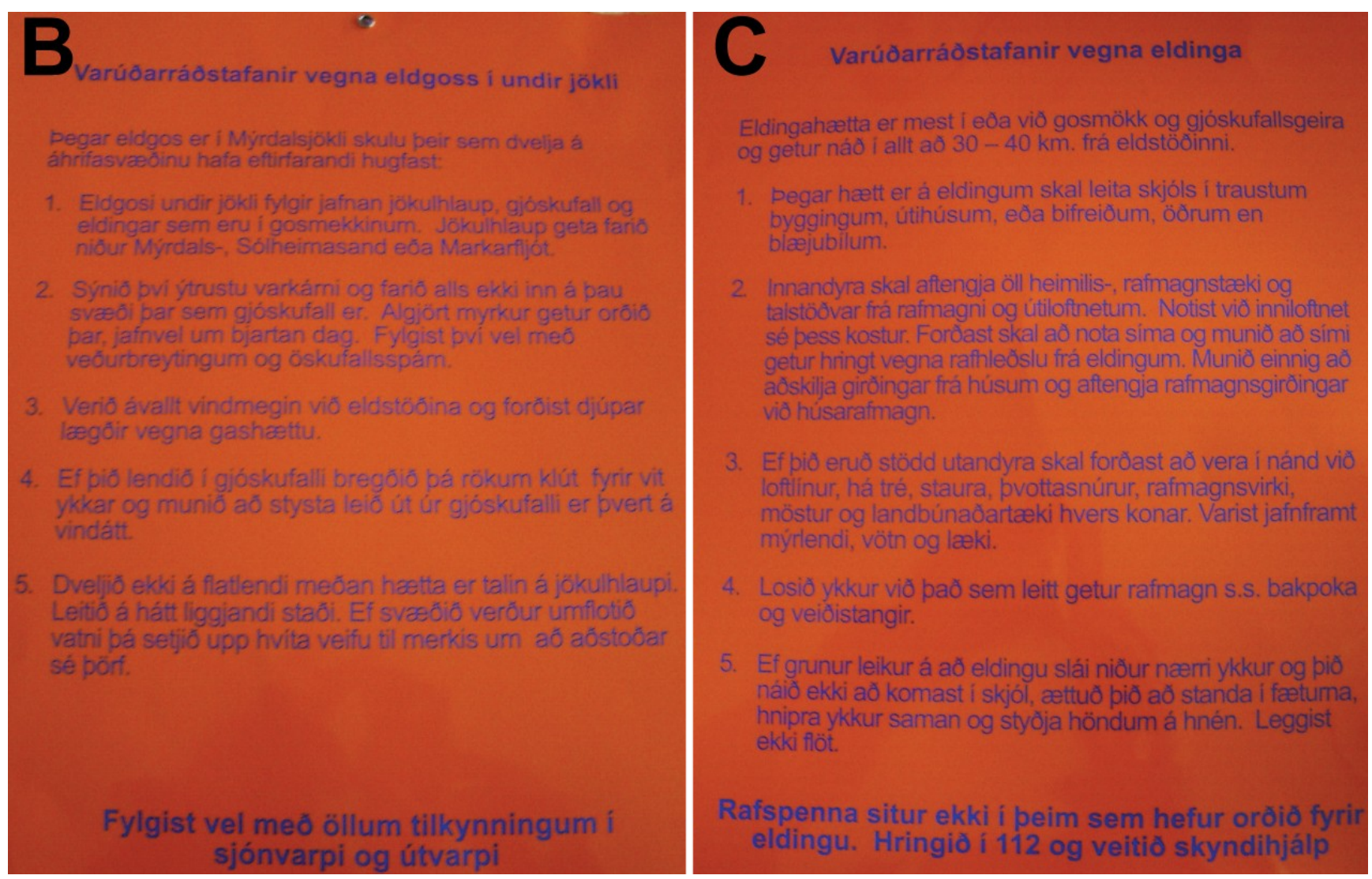

Fig. 2. Continued.

B Precautions due to subglacial eruptions (back left hand side)

During an eruption in Mýrdalsjökull those staying in the hazard area should think of the following:

1. Jökulhlaup, tephra fall and lightning within the plume usually follow a subglacial eruption. Jökulhlaup can go down Mýrdalssandur, Sólheimasandur or the Markarfljót.

2. You should be very careful not enter areas of tephra fall as it can be completely dark even during the day. You should be observant of weather changes and forecast of tephra fall.

3. Always stay on the side of the volcano in the direction of the wind. Avoid deep topographical depressions due to the accumulation of poisonous gases.

4. If you happen to be in tephra fall use a moist cloth to cover your mouth and nose. Remember that the shortest distance from the ash plume is transverse to the wind direction.

5. Do not stay on flat land while the risk from jökulhlaup is predicted. Go to higher areas. If you are in an area that is flooded by water use a white flag to signal for assistance.

Follow all announcements on TV and radio.

C Precautions due to lightning (back right hand side)

The risk for lightning is greatest in or close to the plume and can reach to a distance of $30-40 \mathrm{~km}$ from the volcano itself.

1. When there is the risk of lightning you should seek shelter in secure buildings, out-houses or cars (not convertibles).

2. Unplug all equipment from electricity inside the house and from outdoor antennas including electrical equipment, radio transmitters. Use indoor antennas if possible. Avoid using the telephone and remember that a phone may ring due to electricity from the lightning. Disconnect all fences from the house and unplug electrical fences from the house electricity.

3. If you are outdoors you should avoid being close to high lines, high trees, poles, laundry lines, electrical poles, masts and agricultural equipment of any kind. Try to avoid wetlands, water, and rivers.

4. Unload things that can attract electricity such as rucksacks and fishing rods.

5. If you think that lightning will hit close to you and you cannot find shelter, stay on your feet and crouch down with your hands on your knees. Do not lay flat.

Electricity does not remain in someone who has been hit by lightning. Call 112 and administer first aid.

www.nat-hazards-earth-syst-sci.net/9/251/2009/

Nat. Hazards Earth Syst. Sci., 9, 251-266, 2009 
their perception of the response behaviour of evacuees, and whether or not they viewed the exercise to be a success. In addition to reviewing their perception of the evacuation exercise, the contents of the resident questionnaire were discussed with each person. A tape recorder was used for interviews when permission was granted. Written notes were taken during all interviews and these were transcribed into Microsoft Word® directly after each interview.

\subsection{Conducting questionnaire survey interviews}

Our questionnaire was constructed using a format developed and tested by Bird and Dominey-Howes (2008) and adapted to the geographic and hazard focus of Katla. Further questions were developed based on residents' experience and discussion during the evacuation exercise. The final structure of the specific questions we included were discussed and negotiated with regional emergency personnel to ensure that the survey generated data of value to them in reviewing and improving their emergency management strategies. Therefore, it was important to pre-test our new questionnaire in order to highlight any errors or inconsistencies and to assess whether or not it would generate valuable data which are conducive to the goals of the project (McGuirk and O'Neill, 2005; Parfitt, 2005; Bird and Dominey-Howes, 2008). The pilot phase was carried out with local residents in April 2006. A few minor problems arose with respect to wording and sequencing of two questions. These issues were addressed prior to the main study.

Each questionnaire was printed in English with Icelandic translations. Translations were undertaken by a bilingual translator and then sent to another bilingual translator for verification. Participants were given the choice of conducting the interview in either English or Icelandic. To avoid misinterpretations and miscommunications translations were conducted during the interview and only one translator was used during the course of the study. Special and concise training of translators is critical to ensure that questions are asked exactly as intended and that participant responses are translated fully and completely (Patton, 1990). Our translator received thorough training prior to the study.

Face-to-face questionnaire survey interviews were conducted with local residents in the hazard zone of Rangávallasýsla from May to October 2006. Since this was the first time an evacuation plan had been introduced to these communities and this study was the first of its kind to be held in this region, face-to-face interviews were deemed to be the most effective method for data collection. This is because it allows the interviewer to probe for more detailed responses when required as well as providing clarification if necessary (McGuirk and O'Neill, 2005; Parfitt, 2005).

Participants were recruited using two non-probability qualitative sampling methods. Firstly, a purposive sampling technique was used to target residents living within the hazard zone (i.e. residents registered in each commu- nity within the hazard zone were directly contacted). Purposive sampling is used to deliberately select subjects who are thought to be relevant to the research topic (Sarantakos, 1998). Secondly, a snow-ball sampling technique was employed whereby the first recruitment of participants suggested other residents who might be available to participate during the research period (Sarantakos, 1998). Despite apparent biases with both these sampling techniques, each was deemed appropriate to the study as we were actively seeking knowledge and perception data from residents from each community in the hazard zone. Furthermore, it is not our intention to generalise our results from this sample to the population as a whole, but rather provide a more descriptive preliminary investigation of public perception in this region.

All residents were initially contacted by telephone and interviews were arranged at a time convenient to them. Residents over 18 years of age were targeted and all participants were guaranteed anonymity. Prior to the interview each participant was informed about the purpose of the questionnaire and the proposed use of the data. They were also told that they were free to withdraw from the survey at any given time without consequence. Participants were required to sign $\mathrm{Hu}-$ man Ethics forms to indicate that they agreed with the terms of the survey interview.

The questionnaire was divided into three sections. The first section gathered classification data about the participant. The second section gathered information about their knowledge and perception of Katla, jökulhlaup hazards and emergency procedures. While the third section gathered information about their attendance at, and their perception of, the information meetings on Katla, the evacuation plan and exercise and their use of hazard information available through various media sources. Each section contained both open (free answer) and closed (check-list) questions. In total, the questionnaire contained 52 questions and took approximately $45 \mathrm{~min}$ to complete. However, participants were given as much time as needed to complete the interview. All data were analysed within SPSS ${ }^{\circledR} 15.0$ (Statistical Package for Social Science) and Microsoft Word ${ }^{\circledR}$.

It is beyond the scope of this paper to present data generated from all 52 questions. The questions we present here were selected on the basis of the information they provide (i.e. we believe they have generated significant data which may be useful to emergency managers charged with the responsibility of the ongoing development of risk mitigation procedures). An electronic copy of the questionnaire is available at http://www.nat-hazards-earth-syst-sci. net/9/251/2009/nhess-9-251-2009-supplement..pdf or from the corresponding author.

\section{Results}

Our results are divided into three sections. Firstly, we report on our observations during the evacuation exercise on 26 March 2008. Secondly, information derived from the inter- 
views with emergency management officials is documented. Thirdly, we present results generated from the questionnaire survey interviews with the residents. Comments recorded verbatim are presented in bullet form. In total, 60 individuals were interviewed; 6 emergency personnel and 54 residents.

\subsection{The evacuation exercise of 26 March 2008}

All people involved in the evacuation exercise were instructed to treat it as a real volcanic emergency situation. Details on weather conditions were determined by ICP and emergency personnel were expected to consider wind speed and direction in relation to the development of the volcanic plume. Regular updates of the height and width of the plume were broadcast. Due to the possible hazard from tephra, helicopter pilots refused to fly until EH gave them a direct order. Following this, one helicopter was despatched with a leading scientist to assess the eruption and another was on standby at a nearby airstrip.

All officials within EH held a round table meeting to discuss the progress of the eruption and evacuation every half hour. The Chief of Police of Rangávallasýsla was in charge. Everybody reported to him and he delegated responsibilities as the day progressed. He enforced the need to stay in constant contact with all personnel out in the field. To test the emergency teams for different situations actors were employed to role play residents who refused to evacuate, residents who required medical assistance, people located in a high risk area and in need of helicopter evacuation, and tourists travelling within the hazard zone. The police were instructed to arrest residents if they refused to evacuate (this did not actually occur but residents who were refusing to evacuate were told that they would be arrested in a real evacuation).

The main problem brought to the attention of the Red Cross at the EC was the failure in communication - many residents did not receive the evacuation message and during the evacuation, the EH did not receive this message from the EC. Despite this, approximately $65 \%$ of the population located within the hazard zone of Rangávallasýsla registered at the ECs. Talk amongst the residents at the EC included the communication failure while many voiced their concerns about leaving their animals. Another problem witnessed at the EC was the time it took to manually register residents.

Several instances occurred where residents had not received an evacuation warning but were asked to leave by the sweepers and one family was rescued by the emergency helicopter. Four elderly men arrived at the EC 3 hours after receiving the initial evacuation message. They were surprised that no one had come to check on them. They were not aware they were allocated 30 minutes for preparation before evacuating. Red Cross personnel reported a misunderstanding about the time allocation for evacuation. Some people were anxious to get to the $\mathrm{EC}$ within $30 \mathrm{~min}$ while others thought they had a lot longer. Furthermore, the EC in Hvolsvöllur was not well signposted and some people (including the present authors) could not easily find it.

Regardless of the problems that arose during the evacuation exercise, the general mood at each centre was goodhumoured. Residents joked about the fact that the communication system did not work as planned. Some participants light-heartedly explained that they would have been inundated by flood water due to the fact that they had not received any evacuation message (these residents went to the evacuation centre on their own accord since they knew the exercise was taking place). Resident behaviour and comments indicated that many of them were there for the social aspect of the day.

As a result of our observations during the exercise, specific questions were developed for the questionnaire survey to investigate the failure in communicating the evacuation message, the time allocated to residents to evacuate and whether residents would refuse to evacuate during a real situation.

\subsection{Interviews with emergency management officials}

All emergency management officials gave a clear description of their departments' role and their own personal role during an emergency situation. Each person that was in direct contact with the evacuees reported an overall positive public response. Comments in relation to this included:

- Approximately $65 \%$ of residents took part in the exercise which suggests that people are probably taking this seriously.

- Almost everyone was positive about the evacuation. Some who didn't receive the evacuation message were mixed. Those who were not positive didn't bother coming.

- The evacuees were extremely positive about the exercise. People were willing to participate probably due to the major earthquakes that occurred in 2000.

The evacuation was viewed as a success by all emergency management officials. The main negative comments that arose were attributable to the problem with the communication system. Comments in relation to this included:

- The information that is given to the people is crucial. They need to know how long they have before the flood comes. Also timing of the warnings should allow time for the rescue teams to help the evacuees if the weather conditions are bad. The sweepers can play this role.

- Phone calls and sms (text messages) were not good. People joked about this at the time but once they went home they were probably more concerned that they could have been stuck in a real flood. 
- It is always the communication that breaks down and therefore the sweeper's role should be more concentrated on (providing warning and evacuation information to people). Technology can break down especially in a volcanic disaster. It must be organised as a door-todoor operation.

- We have broadcast advertisements asking people to report if they did not receive a message during the exercise. We have asked them to give their details to the local police and ICP directly so we can try to sort out this problem.

\subsection{Questionnaire survey interviews with residents}

This section is divided as per the three sections of the questionnaire. The first section describes participant demographics based on their responses to classification questions. Participants' responses to both open and closed knowledge and perception questions of Katla, jökulhlaup hazards and emergency procedures are presented in the second section. The third section reports participants' responses to questions relating to their attendance at and their perception of the information meetings on Katla, the evacuation plan and exercise and their use of hazard information available through various media sources. The sequence of questions presented here is the same sequence as that within the questionnaire. Quicklook summary tables have been provided in each section for specific closed questions.

\subsubsection{Participant demographic}

A total of 54 participants were recruited from 67 residents who were approached to take part in the questionnaire survey interviews, providing a response rate of $81 \%$. Our sample included 19\% of participants from Vestur-Eyjafjöll, 26\% of participants from Fljótshlíð, 15\% of participants from Vestur-Landeyjar and 20\% of participants from each AusturLandeyjar and Pykkvibær (Table 1). The majority (57\%) of participants were 51 years of age or over and $57 \%$ of participants lived within $2 \mathrm{~km}$ of either the river Markarfljót or Pverá. Nearly all participants $(98 \%)$ had lived in Iceland most of their lives. Education qualifications of our participants was quite diverse; $28 \%$ held a trade certificate or diploma, $15 \%$ had a university degree or higher and a further $13 \%$ stated an education qualification from another source. Fifty percent of participants were full-time farmers while another $9 \%$ were part-time farmers.

\subsubsection{Residents' knowledge and perception of Katla, jökulhlaup hazard and emergency procedures}

Participants were asked if they could give a brief eruptive history of Katla and a definition of jökulhlaup. In order to be counted as correct for the history of Katla, participants were expected to mention: the last confirmed eruption in 1918; or, the possible eruptions in 1955 and/or 1999; and, the frequency of Katla eruptions as 1, 2 or 3 times per century. However, some participants were counted as correct if they mentioned just one of the above in addition to detailed information about other aspects of Katla. Based on this, a correct response was given by $63 \%$ of participants, $7 \%$ were incorrect while a further $30 \%$ stated they did not know (Table 2). None of the participants in the 18-30 year age group gave a correct answer while only $27 \%$ of the correct answers came from the 31-50 year age group. A correct response for jökulhlaup was credited to answers that defined a flood of water from a glacier. Nearly all participants (94\%) gave a correct response. Only $6 \%$ stated they did not know.

Sixty-seven percent of participants perceive that their region could be affected while $32 \%$ of participants stated no they do not perceive the hazard could affect their region. Eighty percent of participants from the community of VesturEyjafjöll do not perceive the threat to their area and $93 \%$ of these people live within $2 \mathrm{~km}$ of the Markarfljot.

When the participants were asked if they are aware of the emergency procedures they need to follow if a jökulhlaup warning is issued $89 \%$ responded "yes". Seventy-one percent of participants correctly described the evacuation procedure, $19 \%$ stated that they would stay in their homes while the remaining $10 \%$ said that it would depend on:

- If it was occurring right away we would stay. If we had a few hours we might go to Hvolsvöllur;

- I would go to higher ground if at night or during bad weather. If the weather is good and it is daylight I would follow the evacuation procedure and go to Hvolsvöllur; and,

- I would follow the plan to some extent but I would use commonsense especially if they tell me to do something that I know is wrong or dangerous.

Of the participants that live in Vestur-Eyjafjöll 60\% of them said they would stay in their homes. Reasons given to clarify their response were:

- We consider ourselves safe where we live and therefore we will not evacuate. Also, for health reasons I feel better about staying at home;

- All farms in this community are $30-40 \mathrm{~m}$ higher than the river bed;

- I would not evacuate as I feel safe and comfortable in my own home. I am concerned about driving along the road which in my opinion is very dangerous as the road is in the lowland area and close to the river. After 30 minutes we will spend much time in the danger zone driving out of this area; and, 
Table 1. Participant responses from Sect. 1: Classification questions. All data are given as a percentage. Some sections do not equal 100\% due to rounding.

\begin{tabular}{|c|c|c|c|c|c|c|}
\hline $\begin{array}{l}\text { In what region } \\
\text { of Rangávallasýsla } \\
\text { do you live? }\end{array}$ & $\begin{array}{l}\text { Vestur-Eyjafjöll } \\
19\end{array}$ & $\begin{array}{l}\text { Fljótshlíð } \\
26\end{array}$ & $\begin{array}{l}\text { Vestur-Landeyjar } \\
15\end{array}$ & $\begin{array}{l}\text { Austur-Landeyjar } \\
20\end{array}$ & $\begin{array}{l}\text { Pykkvibær } \\
20\end{array}$ & \\
\hline What is your age group? & $\begin{array}{l}18-30 \text { years old } \\
7\end{array}$ & $\begin{array}{l}31-50 \text { years old } \\
35\end{array}$ & $\begin{array}{l}51+\text { years old } \\
57\end{array}$ & & & \\
\hline $\begin{array}{l}\text { How far from the river } \\
\text { do you live? }\end{array}$ & $\begin{array}{l}0<2 \mathrm{~km} \\
57\end{array}$ & $\begin{array}{l}2<5 \mathrm{~km} \\
33\end{array}$ & $\begin{array}{l}5<10 \mathrm{~km} \\
7\end{array}$ & $\begin{array}{l}10+\mathrm{km} \\
2\end{array}$ & & \\
\hline $\begin{array}{l}\text { In which country have } \\
\text { you lived the longest? }\end{array}$ & $\begin{array}{l}\text { Iceland } \\
98\end{array}$ & $\begin{array}{l}\text { Other } \\
2\end{array}$ & & & & \\
\hline \multirow[t]{2}{*}{$\begin{array}{l}\text { What is the highest level } \\
\text { of education you } \\
\text { have completed? }\end{array}$} & $\begin{array}{l}\text { Some } \\
\text { schooling }\end{array}$ & $\begin{array}{l}\text { Educated } \\
6-16 \text { years }\end{array}$ & $\begin{array}{l}\text { Educated } \\
6-20 \text { years }\end{array}$ & $\begin{array}{l}\text { Trade } \\
\text { certificate/ } \\
\text { Diploma }\end{array}$ & $\begin{array}{l}\text { University } \\
\text { degree } \\
\text { or higher }\end{array}$ & Other \\
\hline & 9 & 20 & 15 & 28 & 15 & 13 \\
\hline What is your occupation? & $\begin{array}{l}\text { Full-time farmer } \\
50\end{array}$ & $\begin{array}{l}\text { Part-time farmer } \\
9\end{array}$ & $\begin{array}{l}\text { Other } \\
41\end{array}$ & & & \\
\hline
\end{tabular}

Table 2. Participant responses from Sect. 2: Questions on Katla, jökulhlaup hazards and the warning system. All data are given as a percentage. The second question does not equal 100\% due to rounding. The last question totals more than $100 \%$ as participants were allowed to rank several hazards as the most serious.

\begin{tabular}{|c|c|c|c|}
\hline & Correct & Incorrect & Don't know \\
\hline Can you tell me a brief eruptive history of Katla? & 63 & 7 & 30 \\
\hline How would you define jökulhlaup? & 94 & 0 & 6 \\
\hline \multirow[t]{2}{*}{ Do you think the region where you live could be affected by a jökulhlaup? } & Yes & No & Don't know \\
\hline & 67 & 32 & 2 \\
\hline \multirow{2}{*}{$\begin{array}{l}\text { Are you aware of the emergency procedures you need to follow if a jökulhlaup } \\
\text { warning is issued? }\end{array}$} & Yes & No & \\
\hline & 89 & 11 & \\
\hline \multirow[t]{8}{*}{ What would you define as the most serious hazard in your area if Katla were to erupt? } & Jökulhlaup & 62 & \\
\hline & Ice blocks & 11 & \\
\hline & Lightning & 9 & \\
\hline & Tephra & 26 & \\
\hline & Poisonous gases & 2 & \\
\hline & Lava & 0 & \\
\hline & Tsunami & 0 & \\
\hline & Earthquake & 4 & \\
\hline
\end{tabular}

- We would not evacuate. We would stay here on the farm. It is safer here than on the road. Tephra may block the road and rock fall may occur due to seismic activity.

If a Katla eruption commenced prior to the ICP issuing a warning 55\% of participants stated that they would call 112 or the police (the most popular response) for information while a further $28 \%$ would seek information from the radio, television or internet. Sixty-two percent of participants considered jökulhlaup as the most serious hazard in their area if
Katla were to erupt while tephra was deemed most serious by $26 \%$ (Table 2). We then allocated scores to the rankings (i.e. the most serious hazard was allocated a score of 8; the second most serious was allocated a score of 7 and so on). A nil score was allocated if no ranking was given. Each hazard was ranked at least once (Fig. 3) with jökulhlaup and tephra scoring the highest respectively. 


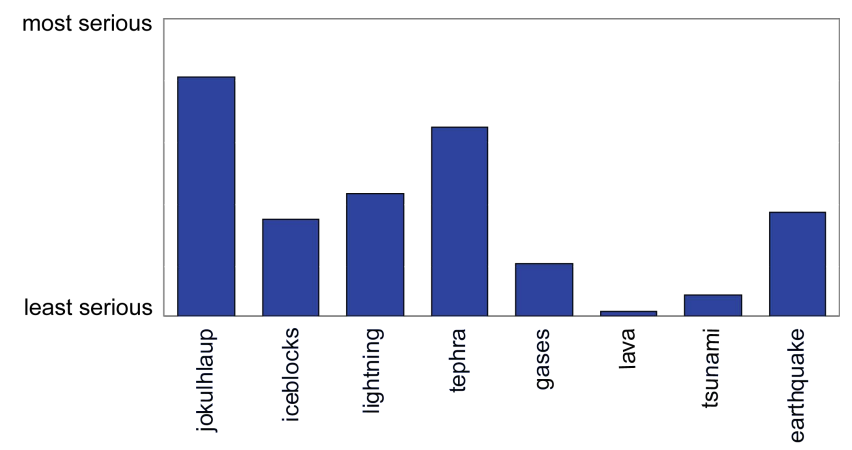

Fig. 3.Participants' perception of the most serious hazards produced during a Katla eruption.

3.3.3 Residents' knowledge and perception of the information meetings on Katla, evacuation plan and exercise, and hazard information in the media

More than half the participants did not attend information meetings on Katla and the proposed evacuation plan and exercise. Reasons stated for not attending included:

- Could not attend due to health reasons;

- At work;

- Too busy when they were on; and,

- Not interested.

Other people stated they did not attend but others within their household did. For those that did attend, we enquired whether they found them informative. Only 5\% of participants did not find them informative. Participant perceptions of the meetings included:

- The simulation and displays were very informative but the sound system was very bad and therefore I could not hear the talks so well.

- It is good to talk about this and make people aware.

- I found the meetings very informative and now there is direct information on what to do if something happens. They educated people and now the local people should not be as afraid as they know what to do.

- I found the meeting informative but they needed more preparation. The people in charge lacked knowledge and those presenting the meetings were not the most experienced. There was no geologist at the last meeting.

- Most of it was nonsense. In the Westman Islands in 1973 everyone had to save themselves and it worked. Here will be the same.
Sixty nine percent of participants did not receive any evacuation message during the exercise (Table 3) and of these, $49 \%$ did not receive a message to their landline. When asked if they always carried their mobile phone $68 \%$ of participants responded "yes". However, only $52 \%$ of farmers carry their mobile phone with them at all times. Of those participants that always carry their mobile phone, $34 \%$ said they do not always have an active connection in their area.

Participation during the evacuation exercise was rather high with $68 \%$ of participants stating they did take part. Their reasons for participation included:

- It is part of my duties as an Icelandic citizen;

- I took part in the evacuation for my own safety and my family's;

- I thought it would be good for people to know how to act;

- I wanted to participate to check how long it would take us to prepare but we didn't complete the whole list on the evacuation sign; and,

- I did take part but I didn't really gain anything from it.

Those who did not take part clarified their actions by stating:

- Too tired and sick;

- I was at work but everyone else in the house took part;

- We would have participated if we had received the evacuation message; and,

- Not interested as I do not perceive that I will be in danger.

Despite some people's negativity toward the evacuation exercise of those who did participate $82 \%$ of them were positive about the exercise.

Thirty minutes was deemed enough time to complete the list as described on the evacuation sign (Fig. 2) before evacuating their property by $52 \%$ of participants. Of the $48 \%$ that stated no or don't know they responded with:

- It is not enough time if you have to let the animals out (as per the instructions);

- $30 \mathrm{~min}$ is not enough time for farmers;

- 30 min may not be enough depending where I am on the farm; and,

- It depends if the kids are at home from school and if I am at work in Hvolsvöllur then I would have to drive back to the house to collect them. 
Table 3. Participant responses from Sect. 3: Questions on Katla information meetings, evacuation plan, evacuation exercise and hazard information available in the media. All data are given as a percentage.

\begin{tabular}{|c|c|c|c|c|}
\hline & None & One & Two & Three \\
\hline How many Katla information meetings did you attend? & 55 & 29 & 4 & 12 \\
\hline How many evacuation messages did you receive on the 26 March $2006 ?$ & 69 & 19 & 6 & 6 \\
\hline If you did not receive any messages did you receive a phone call to the & Yes & No & & \\
\hline landline or your mobile phone? & 51 & 49 & & \\
\hline Do you always carry your mobile phone with you? & 68 & 32 & & \\
\hline Do you always have service coverage to & Yes & No & Don't know & \\
\hline your mobile phone around your area? & 64 & 34 & 2 & \\
\hline \multirow[t]{2}{*}{ Did you take part in the evacuation exercise? } & Yes & No & & \\
\hline & 68 & 32 & & \\
\hline If you did take part in the exercise & Positive & Negative & Mixed & \\
\hline on 26 March 2006 how did you feel about it? & 82 & 8 & 10 & \\
\hline Do you think $30 \mathrm{~min}$ is enough time to complete & Yes & No & Don't know & \\
\hline the list (on the evacuation sign) and evacuate? & 52 & 42 & 6 & \\
\hline Would you follow this procedure if there was a real evacuation? & 74 & 18 & 8 & \\
\hline $\begin{array}{l}\text { Have you looked up the ICP website and familiarised } \\
\text { yourself with information on the possible natural }\end{array}$ & Yes & No & & \\
\hline hazards connected to a Katla eruption? & 19 & 81 & & \\
\hline Have you ever used the Skjálftavefsjá/IMO & & & & \\
\hline website for hazard information? & 26 & 74 & & \\
\hline $\begin{array}{l}\text { Have you followed discussions in the media about } \\
\text { natural hazards connected to a Katla eruption? }\end{array}$ & 89 & 11 & & \\
\hline
\end{tabular}

With these comments in mind it is not surprising that $64 \%$ of farmers do not believe that $30 \mathrm{~min}$ is enough time. Furthermore, several participants were under the impression that they had $30 \mathrm{~min}$ to complete the list and get to the evacuation centre. These people expressed great concern about this because for some of them it takes $30 \mathrm{~min}$ to drive to the closest evacuation centre. These residents were located in Austur and Vestur-Landeyjar (Fig. 1).

Only $19 \%$ of participants had accessed hazard information related to a Katla eruption from the ICP website (www. almannavarnir.is) while $26 \%$ of participants had accessed hazard information from the Skjálftavefsjá (earthquake webviewer) website (drifandi.vedur.is/) and the Icelandic Meteorological Office (IMO) website (www.vedur.is). Media discussions about natural hazards connected to a Katla eruption were followed by $89 \%$ of participants and they sourced this information from television $(88 \%)$, radio $(82 \%)$, newspaper (72\%), information brochures $(54 \%)$, books $(40 \%)$ and the internet (20\%).

Once the questionnaire had been completed the participants were given the opportunity to engage in open discussion. Many participants stated their reluctance to leave their animals and some believe that due to this many farmers may choose to stay at home during an actual evacuation. Some participants would like to see the hazard zone reclassified in order to rank the areas according to the level of risk. These participants felt that people may be complacent as they do not recognise they are actually living in a high risk area and therefore they may prefer to stay at home with their animals during a Katla eruption. Furthermore, many people expressed concern about completing all the instructions on the evacuation list and of particular concern was the instruction to release animals from their enclosures.

Another important message communicated during the discussions was the great concern for tephra fallout. Participants not only feared personal health risks - one participant stated "we have bought ourselves gas masks in case of tephra" - but also related risks associated with the complete darkness that can be experienced during the middle of the day, the threat to agricultural land and the threat to car engines. However, one of the most important statements that arose during these discussions was regarding residents' involvement in the development of the evacuation plan. Several residents objected that they had no say in how the evacuation should be implemented within their communities and following the exercise they were not informed about how successful the drill had been. 


\section{Discussion}

A unique opportunity was presented during and after the evacuation exercise to assess resident knowledge, behaviour and perception of Katla, jökulhlaup hazard and the evacuation plan - a task which had never been done for volcanic hazards in Iceland. A short time window was offered to capture residents' views of the exercise before they forgot this practical experience of risk mitigation. Our small sample size reflects this brief window of opportunity but the data collected provide an in-depth account stemming from a mixed methods approach which incorporated field observations, semi-structured interviews with emergency management officials and questionnaire survey interviews with residents.

The problem of poor communication became evident through our field observations at the EC and was later reiterated during interviews with emergency management officials and residents. The issue of communication between scientists, emergency management officials and the public can inhibit a successful response to evacuation orders (Chester et al., 2002). During the exercise, communication of the evacuation warning was not adequate and some residents were unaware the drill had commenced. This was confirmed in a post-exercise assessment report, where it was stated that the evacuation warning was not communicated effectively to residents (Almannavarnir, 2006). Effective communication not only refers to broadcasting hazard information but also the public and media's ability to understand the nature, meaning and intent of the warning (Dominey-Howes et al., 2007). Communication strategies should be developed with respect to the intended audience and in consideration of social psychological factors which may influence whether or not people assimilate this information and respond accordingly ( $\mathrm{Pa}-$ ton and Johnston, 2001).

The particular role of communication was noted by the president of the International Union of Geodesy and Geophysics (IUGG) during the 2008 International Association of Volcanology and Chemistry of the Earth's Interior (IAVCEI) conference held in Iceland. He emphasised the need for successful communication in volcanic crises and questioned the reliance on modern technology to relay hazard information. This strong dependence on modern technology created problems during the evacuation exercise. To exacerbate this situation, approximately half the farmers in this region stated they do not carry a mobile phone with them at all times and it is these residents who are most likely to be away from a landline. It is therefore critical they receive an evacuation message through an alternative mode. The sweepers in some regions were able to notify those residents who were unaware that the evacuation had commenced. However, through our interviews we were able to ascertain that certain residents were not contacted by phone or sweeper.

Residents were concerned about their own personal safety due to the time it would take them to release livestock from the enclosures. Other residents were concerned about the safety of their animals after being released. They believe it would be safer to leave them inside especially with respect to tephra fall out. Time was a recurring issue as people were confused about the time allocated for them to evacuate particularly with residents located $30 \mathrm{~min}$ from the EC.

Empowerment is described by Paton et al. (2008) as an individual's capacity to have control over their personal affairs and confront hazard issues while receiving the necessary support from emergency management officials. Some residents described a loss of empowerment as they were not involved in the development of the evacuation plan and they were told they had to follow the plan (or be arrested) contrary to their own knowledge and perception. Furthermore, during the interview period residents had not received any feedback regarding the success of the exercise. Despite these shortcomings all the emergency management officials interviewed in this study deemed the evacuation exercise a success. This notion was enforced by the majority of our participants who took part in the exercise.

The questionnaire survey interviews revealed that even though most participants were able to demonstrate an accurate understanding of the eruptive history of Katla and nearly all participants correctly defined jökulhlaup, many (32\%) think their area of residence would not be affected by a jökulhlaup. Alarmingly, $80 \%$ of participants from VesturEyjafjöll share this view even though 93\% of them live within $2 \mathrm{~km}$ of the river. However, these participants clarified their beliefs by stating their homes, like others in this community, are located approximately $30-40 \mathrm{~m}$ above the river bed. Considering that the hazard assessment and consequent hazard map modelled a catastrophic jökulhlaup reaching a maximum flood depth of at least $15 \mathrm{~m}$ upstream of these houses it is understandable that many participants feel it is safer to stay in their homes during a Katla eruption.

Notably, none of the participants from the 18-30 year age group and very few from the 31-50 year age group could correctly describe a brief volcanic history of Katla. An important element for community resilience is inherited memory of volcanic activity (Dominey-Howes and Minos-Minopoulos, 2004). Those residents whose parents experienced the 1918 Katla eruption displayed inherited memory of the eruption. However, this knowledge has not been passed down to the next generation.

Reassuringly, nearly all participants are aware of the emergency procedures they need to follow if an evacuation warning is issued even though some participants stated they would not evacuate. Again, Vestur-Eyjafjöll participant responses stood out from the group with $60 \%$ of them replying they would stay in their homes. In addition to their homes being located higher than the river, the evacuation route for this community travels alongside the Markarfljot. To further exacerbate their concerns residents feel that the evacuation route may place them in a vulnerable position to other hazards such as rock fall and tephra. However, non-hazard re- 
lated factors may also influence residents' decision making process during a Katla eruption. It is possible that socioeconomic constraints such as personal and economic connection to livestock may influence residents' decision on whether or not to evacuate.

Regardless of the communication failures during the evacuation exercise most participants said they would call the emergency number 112 or the police to obtain information about a Katla eruption. However, telephone communication is likely to fail or yield busy signals for specific phone numbers if the network is oversaturated with calls. Exceeding the capacity of regional telecommunication systems complicates the task for emergency management officials and scientific agencies to gather and distribute hazard information by telephone (Gregg et al., 2004). It is therefore optimal for emergency management officials to promote public use of the media during a volcanic crisis. The media can provide an important source of volcanic hazard information for the public and attention should focus on increasing the planned use of this resource and ensuring that it provides consistently accurate information (Johnston et al., 1999). Risk mitigation strategies should include developing a mutually productive relationship between media organisations and emergency management officials in the form of a crisis communication plan to manage the media during a disaster (Hughes and White, 2006).

Participants demonstrated good knowledge of possible hazards that can occur during a future Katla eruption with jökulhlaup, tephra and lightning cited as the most serious. Possessing knowledge of possible hazards ensures that the individual is better equipped to decide whether they should engage in personal preparedness measures and the most appropriate way to achieve this goal (Paton et al., 2008). Our participants' knowledge and concern of tephra was highlighted by one individual who stated that they had taken their own preparedness measures for tephra by purchasing gas masks.

Participant feedback on information provided at the town meetings held to discuss the possibility of a Katla eruption and the proposed evacuation plan was positive. Nearly all participants stated that the scientific information presented through talks, simulations and displays was very informative. A fundamental element of the pathway of information from scientists, emergency management officials and the media is ensuring that it is delivered to the public in a form that represents community needs and functions (Ronan et al., 2000; Gregg et al., 2004). Critical feedback relating to the lack of knowledge and experience of those presenting material at the meetings and technical difficulties should be addressed. Considering that the public are more than just passive receivers of hazard information (Horlick-Jones et al., 2003; Murdock et al., 2003), an integrated approach, that facilitates active participation from both residents and emergency management officials within a risk mitigation framework will help increase public trust, risk acceptance and will- ingness to adopt personal preparedness measures (Paton et al., 2008).

Participation during the evacuation exercise was reasonably good with approximately $65 \%$ of residents taking part. Our sample group of residents reflected this rate with $68 \%$ stating that they took part. Apart from participating in order to improve personal safety and preparedness, many participants stated they took part in the exercise as they believed it was "their duty" to do so. Similarly, Haynes et al. (2008) reported that during an ongoing volcanic crisis on the Caribbean Island of Montserrat participants followed orders because it was the right thing to do.

Although an overwhelming majority of participants have followed media discussions concerning Katla most have not actively sourced hazard information available on the internet. Internet usage was quite low even though Bird et al. (2008) reported that $83 \%$ of Icelandic households have internet connection and $79 \%$ of internet users interact with public authorities. Despite this, it is important to utilise all forms of media as individuals prefer various means of acquiring information (Haynes et al., 2008). Furthermore, the perceived credibility and trust in hazard information can be compromised if forms of distribution are limited (e.g. just pamphlets and TV advertising) (Paton et al., 2008).

The precise location of a future eruption is uncertain therefore making it impossible to predict which direction the jökulhlaup will flow from the glacier margin (Sturkell et al., 2008). Furthermore, adequate preparation for all hazard consequences, such as lightning and tephra, is essential for all residents. The infrequent and complex nature of volcanic hazards increases the public's need to have easily accessible expert information in order to guide their risk management decisions (Paton et al., 2008).

In summary, the key outcomes of this research are:

- Improve the communication system.

- Emphasise the sweepers' role in supporting the dissemination of warning and evacuation information.

- Provide more detailed information on the effects of other volcanic hazards such as tephra, lightning and rock fall and what preparedness measures can be applied to best protect person, property and livestock.

- Ensure that all residents know exactly how much time they have to evacuate.

- Empower residents through involvement in risk mitigation planning.

- Provide feedback on proposed strategy outcomes within a reasonable timeframe (for example, within 3 months after completion).

- Continue to provide hazard information within an appropriate timeframe at town meetings with knowledgeable experts. The timeframe should be based on the 
level of alert (i.e. meetings should be more frequent when there is a higher risk of an eruption).

- Promote the use of all media sources for volcanic hazard information.

\subsection{Further developments and future research}

Sturkell et al. (2008) report on seismic and geodetic measurements from around Katla between 1999 and 2005. Although increasing rates of crustal deformation and seismicity have lowered considerably, they believe that the volcano remains in an agitated state and an eruption in the near future should be expected. Therefore continued development of risk mitigation procedures is essential.

Improvements have been made to the communication system following the failures during the evacuation exercise and plans are underway to test the network (K. Porkelsson, personal communication, 2008). The ICP has confirmed the problem is being rectified and that the chief of police in Rangávallasýsla is charged with the responsibility of testing the communication system during a follow-up exercise (R. Ólafsson, personal communication, 2008). Town meetings were organised with local residents in Rangávallasýsla during 2008. Residents were given the opportunity to voice their concerns with the evacuation plan (K. Porkelsson, personal communication, 2008). In order to better suit community needs and expectations, information gathered during these meetings is being used to develop more appropriate evacuation procedures.

Our preliminary investigation entails a descriptive view of public knowledge and perception from a select group of residents living in each community in the Rangávallasýsla hazard zone. As a result it is impossible to infer that results generated through our research apply to the population as a whole. In order to establish a clear idea of how the general public will respond during a future volcanic event and the complex range of natural and social phenomena that affect the decision making process, more detailed research needs to be conducted with a much larger sample group. Considering that the residents of Rangávallasýsla are not the only ones located in the hazard zone this investigation has been expanded to include residents located in the hazards zones to the south and east of Mýrdalsjökull. A parallel study is also being conducted with tourists and tourism employees within Pórsmörk, a popular tour destination located west of Mýrdalsjökull. Following the recent meetings with residents and current progress toward developing more appropriate evacuation procedures further studies should investigate whether or not they suit community needs and expectations.

\section{Conclusions}

The evacuation plan is the first to be developed and implemented in the municipality of Rangávallasýsla and the
ICP, scientists, local police and rescue teams should be commended for their efforts. However, more work needs to be done to reduce the impact of a future Katla eruption. This can be achieved by addressing some of the main issues raised by our participants. The data provides an insight into how residents interpret their situation in relation to Katla, its associated hazards and their potential response during a crisis. This information highlights the importance of integrating the physical characteristics of Katla's volcanic hazards within context of the communities at risk. Our participants are aware of jökulhlaup, tephra, lightning and rock fall hazards but they have not been provided with enough information to enable them to make an informed decision on whether to evacuate or take shelter in place and how to best protect their livestock. Comparatively, from the information provided, residents in Vestur-Eyjafjöll have been able to conclude that their homes will not be directly affected by jökulhlaup and therefore they are not willing to evacuate. However, non-hazard related factors such as not wanting to leave animals unattended may also influence their decision to evacuate. Furthermore, residents' participation in the evacuation exercise does not necessarily reflect their willingness to evacuate. These examples underline the complex range of natural and social phenomena that affect the individual's decision making process and as a result may inhibit a successful evacuation.

Results from our study highlighted problems associated with communication during the evacuation exercise and the possible need to find alternative modes which do not rely so heavily on technology. In light of this, scientists and emergency management officials should collaborate with media agencies and the public in order to promote the use of media resources and, to ensure hazard information is accurately distributed in an understandable form. Furthermore, the importance of the sweepers' role during an evacuation should be emphasised as they may provide the only communication link between emergency management and farming communities. Recent public meetings which involved residents in risk mitigation efforts are a positive step toward empowering residents with evacuation procedures and preparedness strategies.

This paper presents the first results on residents' knowledge and perception of Katla, jökulhlaup hazard and their views of the evacuation plan and exercise in Rangávallasýsla. The key outcomes, as summarised above, should help provide considerable value to the ongoing development of an effective response capability. Considering this research is the first of its kind in this region the results can be used as a baseline by the ICP for more robust surveys in Iceland's volcanic regions.

Acknowledgements. All participants are graciously thanked for their willingness to participate in this investigation. Gratitude is expressed to Árni Valur Kristinsson for Icelandic translations and Helga Birna Pétursdóttir for field assistance. Funding has been provided by the Department of Environment and Geography and 
the International Office at Macquarie University, Australia; Rannís - the Icelandic Centre for Research (Research Grant \#081260008); Vegagerðin, Iceland (The Icelandic Road Administration); and Landsvirkjun, Iceland. This article benefited from insightful comments from Damian Gore, Chris Gregg, Katharine Haynes, Douglas Paton and an undisclosed reviewer.

Edited by: Giovanni Macedonio

Reviewed by: C. Gregg, D. Paton, K. Haynes and another anonymous referee

\section{References}

Almannavarnir: Skýrsla Bergrisinn 2006, Almannavarnadeild Ríkislögreglustjórans, 24 pp., 2006.

Bird, D. and Dominey-Howes, D.: Tsunami risk mitigation and the issue of public awareness, Australian Journal of Emergency Management, 21, 29-35, 2006.

Bird, D. and Dominey-Howes, D.: Testing the use of a t't'questionnaire survey instrument" to investigate public perceptions of tsunami hazard and risk in Sydney, Australia, Nat. Hazards, 45, 99-122, 2008.

Bird, D., Roberts, M. J., and Dominey-Howes, D.: Usage of an early warning and information system Web-site for real-time seismicity in Iceland, Nat. Hazards, 47, 75-94, 2008.

Björnsson, H.: Subglacial lakes and jökulhlaups in Iceland, Global Planet. Change, 35, 255-271, 2002.

Björnsson, H., Pálsson, F., and Guðmundsson, M. T.: Surface and bedrock topography of the Mýrdalsjökull ice cap, Iceland: The Katla caldera, eruption sites and routes of jökulhlaups, Jökull, 49, 29-46, 2000.

Chester, D. K., Dibben, C. J. L., and Duncan, A. M.: Volcanic hazard assessment in western Europe, J. Volcanol. Geoth. Res., 115, 411-435, 2002.

Dominey-Howes, D. and Minos-Minopoulos, D.: Perceptions of hazard and risk on Santorini, J. Volcanol. Geoth. Res., 137, 285310, 2004.

Dominey-Howes, D., Papathoma-Köhle, M., Bird, D., Mamo, B., and Anning, D.: Letter to the Editor: The Australian Tsunami Warning System and lessons from the 2 April 2007 Solomon Islands tsunami alert in Australia, Nat. Hazards Earth Syst. Sci., 7, 571-572, 2007,

http://www.nat-hazards-earth-syst-sci.net/7/571/2007/.

Gregg, C. E., Houghton, B. F., Paton, D., Swanson, D. A., and Johnston, D. M.: Community preparedness for lava flows from Mauna Loa and Hualalai volcanoes, Kona, Hawai'i, B. Volcanol., 66, 531-540, 2004.

Guðmundsson, M. T.: Subglacial volcanic activity in Iceland, in: Iceland: Modern processes, edited by: Caseldine, C. J., Russell, A., Hardardóttir, J. and Knudsen, Ó., Past Environments, Elsevier, 127-151, 2005.

Guðmundsson, M. T. and Gylfason, Á. G. (Eds.): Hættumat vegna eldgosa og hlaupa frá vestanverðum Mýrdalsjökli og Eyjafjallajökli, Ríkislögreglustjórinn and Háskólaútgáfan, Reykjavík, 210 pp., 2005.

Guðmundsson, M. T., Larsen, G., Höskuldsson, Á., and Gylfason, Á. G.: Volcanic hazards in Iceland, Jökull, 58, 251-268, 2008.

Haynes, K., Barclay, J., and Pidgeon, N.: Volcanic hazard communication using maps: an evaluation of their effectiveness, B.
Volcanol., 70, 123-138, 2007.

Haynes, K., Barclay, J., and Pidgeon, N.: Whose reality counts? Factors affecting the perception of volcanic risk. J. Volcanol. Geoth. Res., 172, 259-272, 2008.

Hólm, S. L. and Kjaran, S. P.: Reiknilíkan fyrir útbreiðslu hlaupa úr Entujökli, in: Hættumat vegan eldgosa og hlaupa frá vestanverðum Mýrdalsjökli og Eyjafjallajökli, edited by: Guðmundsson, M. T. and Gylfason, Á. G., Ríkislögreglustjórinn and Háskólaútgáfan, Reykjavík, 197-210, 2005.

Horlick-Jones, T., Sime, J., and Pidgeon, N.: The social dynamics of environmental risk perception: implications for risk communication research and practice, in: The Social Amplification of Risk, edited by: Pidgeon, N., Kasperson, R. E., and Slovic, P., Cambridge University Press, 262-285, 2003.

Hughes, W. P. and White, P. B.: The media, bushfires and community resilience, in: Disaster Resilience: an integrated approach, edited by: Paton, D. and Johnston, D., Charles C Thomas Publisher Ltd, Springfield, Illinois, 213-225, 2006.

Johnston, D. M., Bebbington, M. S., Lai, C.-D., Houghton, B. F., and Paton, D.: Volcanic hazard perceptions: comparative shifts in knowledge and risk, Disaster Prevention and Management, 8, 118-126, 1999.

Kjartansson, G.: The Steinsholtshlaup, Central-South Iceland on 15 January 1967, Jökull, 17, 249-262, 1967.

Larsen, G.: Holocene eruptions within the Katla volcanic system, south Iceland: Characteristics and environmental impact, Jökull, 49, 1-28, 2000.

Larsen, G., Smith, K., Newton, A., and Knudsen, Ó.: Jökulhlaup til vesturs frá Mýrdalsjökli: Ummerki um forsöguleg hlaup niður Markarfljót, in: Hættumat vegna eldgosa og hlaupa frá vestanverðum Mýrdalsjökli og Eyjafjallajökli, edited by: Guðmundsson, M. T. and Gylfason, Á. G., Ríkislögreglustjórinn and Háskólaútgáfan, Reykjavík, 75-98, 2005.

McGuirk, P. M. and O'Neill, P.: Using Questionnaires in Qualitative Human Geography, in: Qualitative Research Methods in Human Geography, edited by: Hay, I., Oxford University Press, Australia, 147-162, 2005.

Murdock, G., Petts, J., and Horlick-Jones, T.: After amplification: rethinking the role of the media in risk communication, in: The Social Amplification of Risk, edited by: Pidgeon, N., Kasperson, R. E., and Slovic, P., Cambridge University Press, 156-178, 2003.

Parfitt, J.: Questionnaire design and sampling, in: Methods in $\mathrm{Hu}-$ man Geography, edited by: Flowerdew, R. and Martin, D., Pearson Education Limited, England, 78-109, 2005.

Paton, D. and Johnston, D.: Disasters and communities: vulnerability, resilience and preparedness, Disaster Prevention and Management, 10, 270-277, 2001.

Paton, D., Smith, L., Daly, M., and Johnston, D.: Risk perception and volcanic hazard mitigation: individual and social perspectives, J. Volcanol. Geoth. Res., 172, 170-178, 2008.

Patton, M. Q.: Qualitative Evaluation and Research Methods, Sage Publications, Newbury Park, 532 pp., 1990.

Ronan, K. R., Paton, D., Johnston, D. M., and Houghton, B. F.: Managing societal uncertainty in volcanic hazards: a multidisciplinary approach, Disaster Prevention and Management, 9, 339349, 2000.

Russell, A. J., Tweed, F. S., and Knudsen, Ó.: Flash flood at Sólheimajökull heralds the reawakening of an Icelandic subglacial 
volcano, Geology Today, 16, 102-106, 2000.

Sarantakos, S.: Social Research, Macmillan Publishers Australia Pty Ltd, South Yarra, 488 pp., 1998.

Smith, K. T.: Holocene jökulhlaups, glacier fluctuations and palaeoenvironment, Mýrdalsjökull, south Iceland, Institute of Geography, School of Geosciences, University of Edinburgh, Edinburgh, 139 pp., 2004.

Smith, K. T. and Haraldsson, H.: A late Holocene jökulhlaup, Markarfljót, Iceland: nature and impacts, Jökull, 55, 75-86, 2005.
Sturkell, E., Einarsson, P., Roberts, M. J., Geirsson, H., Gudmundsson, M. T., Sigmundsson, F., Pinel, V., Guðmundsson, G. B., Ólafsson, H., and Stefánsson, R.: Seismic and geodetic insights into magma accumulation at Katla subglacial volcano, Iceland: 1999 to 2005, J. Geophys. Res., 113, B03212, doi:10.1029/2006JB004851, 2008.

Thordarson, T. and Larsen, G.: Volcanism in Iceland in historical time: Volcano types, eruption styles and eruptive history, J. Geodyn., 43, 118-152, 2007. 